\title{
Physical and Mechanical Properties of Fish Feed Pellets
}

\author{
El-Sayed G Khater*, Adel H Bahnasawy and Samir A Ali
}

Agricultural Engineering Department - Faculty of Agriculture - Benha University 13736, Egypt

\begin{abstract}
This work presents a useful information about different fish feed pellets, which will be database for the people work in the intensive fish farming which help then in solving many problems concerning the feeding effectiveness and feed handling and storage. The main objective of this work was to study the physical and mechanical properties of fish feed pellets contained different protein ratios and pellets sizes. These properties include: actual diameter, expansion rate, surface area, volume, weight, bulk density, durability, floatability, moisture content, water stability, repose angle and crushing load. The actual diameter of pellets fish feed value ranged from 1.51 to $4.55 \mathrm{~mm}$. The expansion rate of pellets fish feed value ranged from 33.31 to $40.94 \%$. The surface area of pellets fish feed value ranged from 10.57 to $71.13 \mathrm{~mm}^{2}$. The volume of pellets fish feed 4.04 to $79.09 \mathrm{~mm}^{3}$. The weight of 100 pellets value ranged from 0.11 to $5.51 \mathrm{~g}$. The bulk density of pellets of fish feed value ranged from 267.11 to $711.35 \mathrm{~kg} \mathrm{~m}^{-3}$. The durability of pellets of fish feed value ranged from 70.66 to $92.62 \%$. The floatability of pellets of fish feed value ranged from 79.51 to $96.45 \%$. The moisture content of pellets of fish feed value ranged from 16.68 to $17.82 \%$. The water stability of pellets of fish feed value ranged from 54.15 to $91.78 \%$. The repose angle of pellets fish feed value ranged from 27.00 to $38.00^{\circ}$. The crushing load of pellets fish feed value ranged from 6.13 to $33.28 \mathrm{~N}$.
\end{abstract}

Keywords: Physical properties; Mechanical properties; Extruded fish feed; Durability; Floatability; Water stability; Crushing load

\section{Introduction}

Aquaculture is one of the fastest growing food production activities in the world. It plays a significant role in many countries by providing a higher income, better nutrition, and better employment opportunities [1]. Thus, the aqua-feed technology is moving in tandem with the aquaculture growth with the usage of extrusion procedures for the improvement of digestibility $[1,2]$ stated the advantages of extrusion cooking process for aquaculture feed production including improved feed conversion ratio, control of pellet density, greater feed stability in water, better production efficiency and versatility. During extrusion cooking, various reactions take place including thermal treatment, gelatinization, protein denaturation, hydration, texture alteration, partial dehydration, and destruction of microorganisms and other toxic compounds.

Extrusion is the predominant process in the manufacturing of compound fish feed. Extrusion microbial load, reduces the level of thermolabile antinutrients present in plant material and improves the digestibility of dietary components $[3,4]$.

Production of extruded fish feed pellets demands a strict process control to obtain acceptable physical product quality and density specifications. The physical quality of extruded fish feed has become important due to increased use of big bags, bulk transport and pneumatic feed delivery systems. Harsh treatments expose pellets to stress that might increase attrition and product loss [5]. Attrition of feed pellets comprises two phenomena, fragmentation and abrasion, and is normally measured by the combined use of a hardness test (fragmentation) and a pneumatic durability test (fragmentation and abrasion) [6].

Hilton et al. [7] reported that the impact of physical pellet quality on the biological response of the fish has not been studied in detail. Trouts fed extruded feed had prolonged gastric emptying and lower weight gain but higher feed efficiency than trouts fed steam pelleted feeds. The effect was attributed to higher physical and water stability as well as higher water adsorption capacity of the extruded feed. Most published studies on fish nutrition do not report data on physical quality of the feeds. Variation in sinking and floating properties, hardness and physical and water stability might be underlying and uncontrolled variables adding experimental bias that can weaken the interpretation of the biological response.

Studies regarding the physical characteristics of feed pellets involved in seawater [8,9] and freshwater [10] fish farming sand systems have been previously published but there is a complete lack of information regarding the characteristics of the feed employed in the rearing of Mediterranean species.

The physical properties of pellets should be high in order to withstand handling, transportation and pneumatic conveying, without generation of excessive amount of dust and fine particles. Except for this general definition, no standards are established in terms of hardness or durability. Besides, there is a lack of standardization of equipment and measurements for describing physical properties of extruded fish feed. Establishing standards with regard to physical properties is therefore a challenge [11]. In particular, there is a need to establish methods and procedures that can be used to simulate degradation of pellets during conveying in pneumatic feeding devices. Different methods are used to assess durability of the pellets such as the Holmen durability tester, Tumbling box procedure and Lignotest $[6,12,13]$.

Due to the lack of information about the physical and mechanical properties of fish feed pellets which are very important to understand its behavior during processing, transporting, packaging and floatability during fish feeding, therefore, the main aim of this work was to study the physical and mechanical properties of fish feed pellets contained different protein ratios and pellets sizes.

*Corresonding author: El-Sayed G Khater, Agricultural Engineering Department, Faculty of Agriculture, Benha University 13736, Egypt, Tel: +20132467786/+20132467786; E-mail: alsayed.khater@fagr.bu.edu.eg

Received September 05, 2014; Accepted October 07, 2014; Published October 14,2014

Citation: Khater EG, Bahnasawy AH, Ali SA (2014) Physical and Mechanical Properties of Fish Feed Pellets. J Food Process Technol 5: 378 . doi: 10.4172/2157-7110.1000378

Copyright: @ 2014 Khater EG, et al. This is an open-access article distributed under the terms of the Creative Commons Attribution License, which permits unrestricted use, distribution, and reproduction in any medium, provided the original author and source are credited. 


\section{Materials and Methods}

Extruded fish feed with different protein ratios (25, 27, 30 and 32\%) and different sizes $(1,1.5,2.2$ and $3 \mathrm{~mm})$ were produced at Zocontrol processing, Cairo, Egypt. The chemical composition of the fish feed are listed in Table 1.

\section{Measurements}

Physical properties: The dimensions of pellets (diameter and length of each 10 pellets sample) were measured by digital vernier caliper (Model TESA 1p65- Range $0-150 \mathrm{~mm} \pm 0.01 \mathrm{~mm}$, Swiss). The surface area and volume were calculated by measuring the height and radius of 10 feed pellets. The mass was measured by electric digital balance (Model HG - 5000- Range 0-5000 g $\pm 0.01 \mathrm{~g}$, Japan).

The moisture content of randomly selected feed pellets of each category was determined according to [14]. Three samples of each feed pellets were randomly selected and weighed on an electric digital balance. Drying oven (Fisher Scientific Isotemp Oven, Model 655F Cat. No. 13-245-655, Fisher Scientific, Toronto, Ontario, Canada) at $105^{\circ} \mathrm{C}$ until a constant weight was used to measure the moisture content.

The bulk density was a measurement of a feed mass per unit volume of space the feed occupies [15]. For each case, the determination was replicated three times and the mean was considered.

Durability was measured using a Holmen tester (BorregaardLignoTech, Hull, UK). Three samples of approximately $100 \mathrm{~g}$ of pellets were weighed into the analytical instrument and run for $120 \mathrm{~s}$. The amount of material left in the sieve was weighed and durability expressed as percentage the material left on the sieve.

Floatability of each replicate feeds was tested using $100 \mathrm{ml}$ beakers. The characteristics of 10 pellets (floated or sunk) were noted after 20 min. Water stability (WS) was measured as the ratio of the pellets retained on a wire mesh screen after immersion of 3-4 $\mathrm{g}$ of each replicate feeds in $100 \mathrm{ml}$ water for $20 \mathrm{~min}$ and oven-drying at $105^{\circ} \mathrm{C}$ for $24 \mathrm{~h}$ to whole pellets at the start [16].

Expansion rate (ER) was calculated using Eq. 1 after measuring the final diameters of 10 pellets (Df) of each replicate:

Where:-

Di is the initial die diameter, $\mathrm{mm}$

Mechanical properties: The angle of repose is the minimum angle at which any piled-up bulky or loose material will stand without falling downhill. There is a minimum angle or maximum slope the pellets will maintain due to the forces of gravity and the effect of friction between the particles of pellets. The angle is calculated between the peak of the pile and the horizontal ground [17].

Crushing load implies the partial or complete destruction of pellets, feed pellet was sat upon a flat plate until the cross-head of a handmade apparatus was brought in contact with the pellet and compression force was applied by adding weights or loads until permanent (destruction) was caused and then the loads were recorded [18].

\section{Results and Discussions}

\section{Physical properties}

The mean diameter and expansion rate of fish feed pellets: Table 2 shows the mean values, standard deviation (SD) and coefficients of variation $(\mathrm{CV})$ of the actual diameter and expansion rate of the fish feed pellets. It shows that the average of actual diameter and expansion rate of the fish feed pellets were $1.54 \pm 0.14,2.45 \pm 0.13,3.39 \pm 0.17$ and $4.40 \pm 0.26 \mathrm{~mm}$ and $34.70 \pm 5.82,38.67 \pm 3.19,34.90 \pm 3.10$ and $32.23 \pm 3.85 \%$ for $1.0,1.5,2.2$ and $3.0 \mathrm{~mm}$ pellets sizes, respectively, at $25 \%$ protein ratio. The coefficients of variation of the actual diameter data recorded the highest value $(0.09)$ on the $1.0 \mathrm{~mm}$ pellets sizes, while the minimum value (0.05) on the 1.5 and $2.2 \mathrm{~mm}$ pellets sizes at $25 \%$ protein ratio. Also, the highest value the $\mathrm{CV}$ values of the expansion rate was 0.17 for $1.0 \mathrm{~mm}$ pellets sizes, while the minimum value was 0.08 for the $1.5 \mathrm{~mm}$ pellets sizes at the same protein ratio.

The results indicate that the average of actual diameter and expansion rate of the fish feed pellets were $1.52 \pm 0.13,2.44 \pm 0.11,3.34$ \pm 0.15 and $4.55 \pm 0.30 \mathrm{~mm}$ and $33.60 \pm 5.60,38.46 \pm 2.73,34.03 \pm 2.98$ and $33.79 \pm 4.50 \%$ for $1.0,1.5,2.2$ and $3.0 \mathrm{~mm}$ pellets sizes, respectively, at $27 \%$ protein ratio. The highest value of $\mathrm{CV}$ of the actual diameter (0.09) was found for $1 \mathrm{~mm}$ pellets sizes and the lowest value (0.04) was found for $1.5 \mathrm{~mm}$ pellets sizes at $27 \%$ protein ratio. The same trend for $\mathrm{CV}$ was happened with the expansion rate.

The results also indicate that the average of actual diameter and expansion rate of the fish feed pellets were $1.51 \pm 0.14,2.54 \pm 0.11,3.40$ \pm 0.13 and $4.34 \pm 0.31 \mathrm{~mm}$ and $33.31 \pm 6.45,40.94 \pm 2.52,35.24 \pm 2.50$ and $31.32 \pm 4.91 \%$ for $1.0,1.5,2.2$ and $3.0 \mathrm{~mm}$ pellets sizes, respectively, at $30 \%$ protein ratio. The highest value of CV for actual diameter and expansion rate were 0.10 and 0.19 , respectively, were found for $1 \mathrm{~mm}$ pellets sizes. The lowest value of CV of actual diameter (0.04) was found for 1.5 and $2.2 \mathrm{~mm}$ pellets sizes, while the lowest value of $\mathrm{CV}$ of expansion rate $(0.06)$ was found for $1.5 \mathrm{~mm}$ pellets sizes at the same protein ratio.

On the other hand, the average of actual diameter and expansion rate of the fish feed pellets were $1.51 \pm 0.09,2.37 \pm 0.10,3.39 \pm 0.17$ and $4.55 \pm 0.22 \mathrm{~mm}$ and $33.44 \pm 3.89,36.53 \pm 2.67,34.94 \pm 3.21$ and 33.93 $\pm 3.21 \%$ for $1.0,1.5,2.2$ and $3.0 \mathrm{~mm}$ pellets sizes, respectively, at $32 \%$ protein ratio. The highest value of $\mathrm{CV}$ of the actual diameter (0.06) was found for $1 \mathrm{~mm}$ pellets sizes and the lowest value (0.04) was found for $1.5 \mathrm{~mm}$ pellets sizes at $32 \%$ protein ratio. The same trend for CV was happened with the expansion rate.

Multiple regression analysis has resulted in a good relationship between the mean of Actual Diameter (AD), pellet sizes (PS) and protein ratios (PR), where, the mean of actual diameter has a high correlation with both $\mathrm{PS}$ and $\mathrm{PR}$ with $\mathrm{r}^{2}$ of 0.991 at $\mathrm{P}<0.001$. The mean of Expansion Rate (ER), Pellet Sizes (PS) and Protein Ratios (PR) relationship with $\mathrm{r}^{2}$ of 0.881 at $\mathrm{P}<0.001$. The best forms were as follows:

$$
\begin{array}{ll}
\mathrm{AD}=0.158+1.445 \mathrm{PS}+0.0004 \mathrm{PR} & \mathrm{R}^{2}=0.991 \\
\mathrm{ER}=38.498-1.243 \mathrm{PS}-0.039 \mathrm{PR} & \mathrm{R}^{2}=0.881
\end{array}
$$

Where:

$\mathrm{AD}$ is the actual diameter of pellets fish feed, $\mathrm{mm}$

ER is the expansion rate of pellets fish feed, \%

PS is the pellet sizes, $\mathrm{mm}$

$\mathrm{PR}$ is the protein ratios, \%

\begin{tabular}{|l|c|c|c|c|}
\hline \multirow{2}{*}{ Ingredients } & \multicolumn{4}{|c|}{ Protein Ratio of Fish Feed, \% } \\
\cline { 2 - 5 } & $\mathbf{2 5}$ & $\mathbf{2 7}$ & $\mathbf{3 0}$ & $\mathbf{3 2}$ \\
\hline Fish Meal, \% & 8 & 10 & 11 & 12 \\
\hline Soybean, \% & 29 & 33 & 38 & 42 \\
\hline Yellow Corn, \% & 24 & 20 & 18 & 17 \\
\hline Wheat Bran, \% & 30 & 28 & 24 & 20 \\
\hline Fish additives, \% & 9 & 9 & 9 & 9 \\
\hline
\end{tabular}

Table 1: Chemical composition of the feed fish 
Citation: Khater EG, Bahnasawy AH, Ali SA (2014) Physical and Mechanical Properties of Fish Feed Pellets. J Food Process Technol 5: 378 . doi: 10.4172/2157-7110.1000378

\begin{tabular}{|c|c|c|c|c|c|c|c|c|c|}
\hline \multirow{3}{*}{\multicolumn{2}{|c|}{$\begin{array}{l}\text { Protein ratio } \\
(\%)\end{array}$}} & \multicolumn{4}{|c|}{ Pellet Sizes (mm) } & \multicolumn{4}{|c|}{ Pellet Sizes (mm) } \\
\hline & & 1 & 1.5 & 2.2 & 3 & 1 & 1.5 & 2.2 & 3 \\
\hline & & \multicolumn{4}{|c|}{ Actual Diameter (mm) } & \multicolumn{4}{|c|}{ Expansion Rate (\%) } \\
\hline \multirow{3}{*}{25} & Mean & 1.54 & 2.45 & 3.39 & 4.40 & 34.72 & 38.67 & 34.90 & 32.23 \\
\hline & SD & 0.14 & 0.13 & 0.17 & 0.26 & 5.82 & 3.19 & 3.10 & 3.85 \\
\hline & CV & 0.09 & 0.05 & 0.05 & 0.06 & 0.17 & 0.08 & 0.09 & 0.12 \\
\hline \multirow{3}{*}{27} & Mean & 1.52 & 2.44 & 3.34 & 4.55 & 33.60 & 38.46 & 34.03 & 33.79 \\
\hline & SD & 0.13 & 0.11 & 0.15 & 0.30 & 5.60 & 2.73 & 2.98 & 4.50 \\
\hline & cV & 0.09 & 0.04 & 0.05 & 0.07 & 0.17 & 0.07 & 0.09 & 0.13 \\
\hline \multirow{3}{*}{30} & Mean & 1.51 & 2.54 & 3.40 & 4.34 & 33.31 & 40.94 & 35.24 & 31.32 \\
\hline & SD & 0.14 & 0.11 & 0.13 & 0.31 & 6.45 & 2.52 & 2.50 & 4.91 \\
\hline & CV & 0.10 & 0.04 & 0.04 & 0.07 & 0.19 & 0.06 & 0.07 & 0.16 \\
\hline \multirow{3}{*}{32} & Mean & 1.51 & 2.37 & 3.39 & 4.55 & 33.44 & 36.53 & 34.94 & 33.93 \\
\hline & SD & 0.09 & 0.10 & 0.17 & 0.22 & 3.89 & 2.67 & 3.21 & 3.21 \\
\hline & CV & 0.06 & 0.04 & 0.05 & 0.05 & 0.12 & 0.07 & 0.09 & 0.09 \\
\hline
\end{tabular}

SD: Standard Division

CV: Coefficient of Variation

Table 2: The mean of actual diameter and expansion rate of feed fish pellets.

Surface area and volume of fish feed pellets: Table 3 shows the mean values, Standard Deviation (SD) and Coefficients of Variation $(\mathrm{CV})$ of the surface area and volume of the fish feed pellets. It shows that the average of surface area and volume of the fish feed pellets were $11.83 \pm 2.54,23.02 \pm 3.65,41.24 \pm 9.19$ and $71.13 \pm 9.96 \mathrm{~mm}^{2}$ and 4.64 $\pm 1.38,14.19 \pm 2.88,32.80 \pm 3.98$ and $79.09 \pm 13.04 \mathrm{~mm}^{3}$ for $1.0,1.5,2.2$ and $3.0 \mathrm{~mm}$ pellets sizes, respectively, at $25 \%$ protein ratio. The highest value of CV of the surface area (0.22) for the $2.0 \mathrm{~mm}$ pellets sizes, while the minimum value $(0.14)$ for the $3.0 \mathrm{~mm}$ pellets sizes at $25 \%$ protein ratio. Also, the highest value the $\mathrm{CV}$ values of the volume was 0.30 for $1.0 \mathrm{~mm}$ pellets sizes, while the minimum value was 0.12 for the $2.0 \mathrm{~mm}$ pellets sizes at the same protein ratio.

The results indicate that the highest value of surface area and volume of the fish feed pellets were $71.13 \pm 9.96 \mathrm{~mm}^{2}$ and $79.09 \pm 13.04$ $\mathrm{mm}^{3}$, respectively, at the pellet sizes $3.0 \mathrm{~mm}$ with $25 \%$ protein ratio. The lowest value of surface area and volume of the fish feed pellets were $10.57 \pm 1.69 \mathrm{~mm}^{2}$ and $4.04 \pm 0.98 \mathrm{~mm}^{3}$, respectively, for the pellet sizes of $1.0 \mathrm{~mm}$ with $30 \%$ protein ratio. The highest value of $\mathrm{CV}$ of the surface area $(0.92)$ was found for $3.0 \mathrm{~mm}$ pellets sizes with $32 \%$ protein ratio and the lowest value (0.05) was found for $2.2 \mathrm{~mm}$ pellets sizes at $27 \%$ protein ratio. The highest value of $\mathrm{CV}$ of the volume $(0.30)$ was found for $1.0 \mathrm{~mm}$ pellets sizes at $25 \%$ protein ratio and the lowest value (0.08) was found for $2.2 \mathrm{~mm}$ pellets sizes at $27 \%$ protein ratio.

Multiple regression analysis has resulted in a good relationship between the mean of Surface Area (SA), Pellet Sizes (PS) and Protein Ratios (PR), where, the mean surface area has a high correlation with both PS and PR with $\mathrm{r}^{2}$ of 0.969 at $\mathrm{P}<0.001$. The mean of volume (V), pellet sizes (PS) and protein ratios (PR) relationship with $\mathrm{r}^{2}$ of 0.936 at $\mathrm{P}<0.001$. The best forms were as follows:

$$
\begin{array}{ll}
\mathrm{SA}=-2.714+27.669 \mathrm{PS}-0.5702 \mathrm{PR} & \mathrm{R}^{2}=0.969 \\
\mathrm{~V}=-28.5391+35.2699 \mathrm{PS}-0.2864 \mathrm{PR} & \mathrm{R}^{2}=0.936
\end{array}
$$

\section{Where:}

SA is the surface area of pellets fish feed, $\mathrm{mm}^{2}$

$\mathrm{V}$ is the volume of pellets fish feed, $\mathrm{mm}^{3}$

Weight and bulk density of fish feed pellets: Table 4 shows the mean values, standard deviation (SD) and coefficients of variation $(\mathrm{CV})$ of the weight and bulk density of the fish feed pellets. The results indicated that the mean weight and bulk density of the fish feed pellets increases with increasing the pellet sizes and protein ratio. It indicated that when the pellet sizes increased from 1.0 to $3.0 \mathrm{~mm}$, the mean weight of 100 pellets and bulk density increased from $0.28 \pm 0.038$ to $5.51 \pm 0.237$ $\mathrm{g}$ and $630.02 \pm 156.99$ to $711.35 \pm 105.60 \mathrm{~kg} \mathrm{~m}^{-3}$, respectively, at $25 \%$ protein ratio. The highest value of $\mathrm{CV}$ for weight $(0.137)$ was found for $1.0 \mathrm{~mm}$ pellets sizes, while the highest value of CV for bulk density (0.25) was found for $1.0 \mathrm{~mm}$ pellets sizes. The lowest value of CV of weight $(0.030)$ was found for $2.2 \mathrm{~mm}$ pellets sizes, while the lowest value of $\mathrm{CV}$ of bulk density (0.11) was found for $2.2 \mathrm{~mm}$ pellets sizes at the same protein ratio.

Also, the mean weight of 100 pellets and bulk density increased from $0.11 \pm 0.006$ to $3.70 \pm 0.173 \mathrm{~g}$ and $267.11 \pm 117.65$ to $505.78 \pm$ $63.61 \mathrm{~kg} \mathrm{~m}^{-3}$, respectively, at $32 \%$ protein ratio. The highest value of CV for weight (0.052) was found of 1.0 and $1.5 \mathrm{~mm}$ pellets sizes, while the highest value of CV for bulk density (0.29) was found for $1.0 \mathrm{~mm}$ pellets sizes. The lowest value of $\mathrm{CV}$ of weight $(0.028)$ was found for 2.2 $\mathrm{mm}$ pellets sizes, while the lowest value of $\mathrm{CV}$ of bulk density $(0.13)$ was found for 2.2 and $3.0 \mathrm{~mm}$ pellets sizes at $32 \%$ protein ratio.

The lowest value of weight of 100 pellets and bulk density were 0.11 $\pm 0.006 \mathrm{~g}$ and $267.11 \pm 117.65 \mathrm{~kg} \mathrm{~m}^{-1}$, respectively, at the pellet sizes $1.0 \mathrm{~mm}$ with $32 \%$ protein ratio and the highest value of weight of 100 pellets and bulk density were $5.51 \pm 0.043 \mathrm{~g}$ and $711.35 \pm 105.60 \mathrm{~kg} \mathrm{~m}^{-3}$,

\begin{tabular}{|c|c|c|c|c|c|c|c|c|c|}
\hline \multirow{3}{*}{\multicolumn{2}{|c|}{$\begin{array}{l}\text { Protein ratio } \\
(\%)\end{array}$}} & \multicolumn{4}{|c|}{ Pellet Sizes (mm) } & \multicolumn{4}{|c|}{ Pellet Sizes (mm) } \\
\hline & & 1 & 1.5 & 2.2 & 3 & 1 & 1.5 & 2.2 & 3 \\
\hline & & \multicolumn{4}{|c|}{ area $\left(\mathrm{mm}^{2}\right)$} & \multicolumn{4}{|c|}{ Volume $\left(\mathrm{mm}^{3}\right)$} \\
\hline \multirow{3}{*}{25} & Mean & 11.83 & 23.02 & 41.24 & 71.13 & 4.64 & 14.19 & 32.80 & 79.09 \\
\hline & SD & 2.54 & 3.65 & 9.19 & 9.96 & 1.38 & 2.88 & 3.98 & 13.04 \\
\hline & CV & 0.21 & 0.16 & 0.22 & 0.14 & 0.30 & 0.20 & 0.12 & 0.16 \\
\hline \multirow{3}{*}{27} & Mean & 11.79 & 20.79 & 37.44 & 67.08 & 4.51 & 12.73 & 31.29 & 75.74 \\
\hline & SD & 1.82 & 1.77 & 2.00 & 6.50 & 1.01 & 1.63 & 2.47 & 11.37 \\
\hline & CV & 0.15 & 0.09 & 0.05 & 0.32 & 0.22 & 0.13 & 0.08 & 0.15 \\
\hline \multirow{3}{*}{30} & Mean & 10.57 & 21.99 & 37.52 & 65.32 & 4.04 & 13.97 & 31.97 & 71.86 \\
\hline & SD & 1.69 & 1.80 & 2.74 & 8.69 & 0.98 & 1.52 & 3.28 & 12.14 \\
\hline & CV & 0.16 & 0.08 & 0.07 & 0.13 & 0.22 & 0.11 & 0.11 & 0.17 \\
\hline \multirow{3}{*}{32} & Mean & 11.18 & 20.40 & 32.46 & 65.01 & 4.24 & 12.09 & 31.82 & 74.12 \\
\hline & SD & 1.75 & 2.05 & 3.63 & 5.99 & 0.86 & 1.47 & 4.21 & 9.25 \\
\hline & CV & 0.16 & 0.10 & 0.10 & 0.92 & 0.20 & 0.12 & 0.13 & 0.12 \\
\hline
\end{tabular}
respectively, at the pellet sizes $3.0 \mathrm{~mm}$ with $25 \%$ protein ratio.

SD: Standard Division

CV: Coefficient of Variation

\begin{tabular}{|c|c|c|c|c|c|c|c|c|c|}
\hline \multirow{3}{*}{\multicolumn{2}{|c|}{$\begin{array}{l}\text { Protein ratio } \\
(\%)\end{array}$}} & \multicolumn{4}{|c|}{ Pellet Sizes (mm) } & \multicolumn{4}{|c|}{ Pellet Sizes (mm) } \\
\hline & & 1 & 1.5 & 2.2 & 3 & 1 & 1.5 & 2.2 & 3 \\
\hline & & \multicolumn{4}{|c|}{100 pellets weight $(\mathrm{g})$} & \multicolumn{4}{|c|}{ Bulk density $\left(\mathrm{kg} \mathrm{m}^{-3}\right)$} \\
\hline \multirow{3}{*}{25} & Mean & 0.28 & 1.15 & 3.12 & 5.51 & 630.02 & 696.23 & 702.40 & 711.35 \\
\hline & SD & 0.038 & 0.087 & 0.094 & 0.237 & 156.99 & 142.03 & 98.11 & 105.60 \\
\hline & CV & 0.137 & 0.075 & 0.030 & 0.043 & 0.25 & 0.18 & 0.11 & 0.15 \\
\hline \multirow{3}{*}{27} & Mean & 0.19 & 0.85 & 2.45 & 4.93 & 442.67 & 681.07 & 816.14 & 663.37 \\
\hline & SD & 0.030 & 0.035 & 0.058 & 0. & 13 & 129.95 & 76.30 & 102.96 \\
\hline & CV & 0.159 & 0.065 & 0.023 & 0. & 0.31 & 0.19 & 0.09 & 0.16 \\
\hline \multirow{3}{*}{30} & Mean & 0.13 & 0.69 & 2.10 & 4.45 & 330.01 & 500.77 & 663.79 & 635.33 \\
\hline & SD & 0.017 & 0.304 & 0.00 & 0.029 & 114.25 & 101.01 & 77.18 & 108.58 \\
\hline & CV & 0.133 & 0.044 & 0.00 & 0.006 & 0.35 & 0.20 & 0.12 & 0.17 \\
\hline \multirow{3}{*}{32} & Mean & 0.11 & 0.55 & 1.99 & 3.70 & 267.11 & 462.98 & 634.50 & 505.78 \\
\hline & SD & 0.006 & 0.029 & 0.056 & 0.173 & 77.4 & 117.65 & 79.79 & 63.61 \\
\hline & CV & 0.052 & 0.052 & 0.028 & 0.047 & 0.29 & 0.25 & 0.13 & 0.13 \\
\hline
\end{tabular}

Table 3: The mean of surface area and volume of feed fish pellets

SD: Standard Division

CV: Coefficient of Variation

Table 4: The mean of weight and bulk density of pellets feed fish 
Citation: Khater EG, Bahnasawy AH, Ali SA (2014) Physical and Mechanical Properties of Fish Feed Pellets. J Food Process Technol 5: 378. doi: 10.4172/2157-7110.1000378

These results indicated that the bulk density of the fish feed pellets increases with increasing the expansion rate. These results were in agreement with those obtained by [19-21].

Multiple regression analysis has resulted in a good relationship between the mean of weight (W), pellet sizes (PS) and protein ratios (PR), where, the mean weight has a high correlation with both PS and $\mathrm{PR}$ with $\mathrm{r}^{2}$ of 0.961 at $\mathrm{P}<0.001$. The Bulk Density (BD), Pellet Sizes (PS) and Protein Ratios (PR) relationship with $\mathrm{r}^{2}$ of 0.891 at $\mathrm{P}<0.001$. The best forms were as follows:

$$
\begin{array}{ll}
\mathrm{W}=1.194+2.2726 \mathrm{PS}-0.1246 \mathrm{PR} & \mathrm{R}^{2}=0.961 \\
\mathrm{BD}=1306.798+103.597 \mathrm{PS}-32.359 \mathrm{PR} & \mathrm{R}^{2}=0.891
\end{array}
$$

Where:

$\mathrm{W}$ is the weight of pellets fish feed, $\mathrm{g}$

$\mathrm{BD}$ is the bulk density of pellets fish feed, $\mathrm{kg} \mathrm{m}^{-3}$

Durability and floatability of fish feed pellets: Table 5 shows the mean values, standard deviation (SD) and Coefficients of Variation (CV) of the durability and floatability of the fish feed pellets. The results indicated that the mean durability of the fish feed pellets decreases with increasing the pellet sizes and protein ratio. It indicated that when the pellet sizes increased from 1.0 to $3.0 \mathrm{~mm}$, the mean durability decreased from $92.62 \pm 3.86$ to $75.64 \pm 5.73 \%$ at $25 \%$ protein ratio. The highest value of CV for durability ( 0.08$)$ was found for $3.0 \mathrm{~mm}$ pellet sizes. The lowest value of $\mathrm{CV}$ of durability (0.03) was found for $1.5 \mathrm{~mm}$ pellet sizes at $25 \%$ protein ratio. The mean durability decreased from $87.52 \pm$ 4.44 to $70.66 \pm 4.22 \%$ at $32 \%$ protein ratio. The highest value of $\mathrm{CV}$ for durability (0.06) was found for $3.0 \mathrm{~mm}$ pellet sizes. The lowest value of $\mathrm{CV}$ of durability (0.04) was found for $2.2 \mathrm{~mm}$ pellet sizes. The lowest value of durability was $70.66 \pm 4.22 \%$ at the pellet sizes $3.0 \mathrm{~mm}$ with 32 $\%$ protein ratio and the highest value of durability was $92.62 \pm 3.86 \%$ at the pellet sizes $1.0 \mathrm{~mm}$ with $25 \%$ protein ratio.

The results indicated that the mean floatability of the fish feed pellets decreases with increasing the pellet sizes and decreasing protein ratio. It indicated that when the pellet sizes increased from 1.0 to 3.0 $\mathrm{mm}$, the mean floatability decreased from $96.45 \pm 1.02$ to $79.51 \pm 2.01 \%$ at $25 \%$ protein ratio. The highest value of CV for floatability ( 0.03$)$ was found for $3.0 \mathrm{~mm}$ pellet sizes. The lowest value of CV of floatability (0.01) was found for $1.0 \mathrm{~mm}$ pellet sizes at $25 \%$ protein ratio. The mean floatability decreased from $98.00 \pm 0.00$ to $87.82 \pm 2.01 \%$ at $32 \%$ protein ratio. The highest value of CV for floatability $(0.02)$ was found for 1.5 , 2.2 and $3.0 \mathrm{~mm}$ pellet sizes. The lowest value of $\mathrm{CV}$ of floatability $(0.00)$ was found for $1.0 \mathrm{~mm}$ pellet sizes at $32 \%$ protein ratio. The lowest value of floatability was $79.51 \pm 2.01 \%$ at the pellet sizes $3.0 \mathrm{~mm}$ with $25 \%$ protein ratio and the highest value of durability was $98.00 \pm 0.00 \%$ at the pellet sizes $1.0 \mathrm{~mm}$ with $32 \%$ protein ratio.

These results indicated that the durability of the fish feed pellets increases with increasing the expansion rate. These results were in agreement with those obtained by $[22,23]$.

Multiple regression analysis was carried out to get a relationship between the mean of durability (PD), pellet sizes (PS) and protein ratios (PR), where, the mean durability has a high correlation with both $\mathrm{PS}$ and PR with $\mathrm{r}^{2}$ of 0.982 at $\mathrm{P}<0.001$. The mean of floatability (PF), pellet sizes (PS) and protein ratios (PR) relationship with $\mathrm{r}^{2}$ of 0.876 at $\mathrm{P}<0.001$. The best forms were as follows:

$$
\begin{array}{ll}
\mathrm{PD}=122.8685-8.058 \mathrm{PS}-0.9013 \mathrm{PR} & \mathrm{R}^{2}=0.982 \\
\mathrm{P} F=96.854-6.205 \mathrm{PS}+0.4637 \mathrm{PR} & \mathrm{R}^{2}=0.876
\end{array}
$$

\section{Where:}

PD is the durability of pellets fish feed, \%

$\mathrm{PF}$ is the floatability of pellets fish feed, \%
Moisture content and water stability of fish feed pellets: Table 6 shows the mean values, standard deviation (SD) and coefficients of variation $(\mathrm{CV})$ of the moisture content and water stability of the fish feed pellets. It shows that the average of moisture content of the fish feed pellets was $16.72 \pm 2.11,17.01 \pm 2.03,16.92 \pm 1.75$ and $17.35 \pm$ $1.32 \%$ for $1.0,1.5,2.2$ and $3.0 \mathrm{~mm}$ pellets sizes, respectively, at $25 \%$ protein ratio. The highest value of $\mathrm{CV}$ of the moisture content $(0.13)$ on the $1.0 \mathrm{~mm}$ pellet sizes, while the minimum value $(0.08)$ on the $3.0 \mathrm{~mm}$ pellet sizes at $25 \%$ protein ratio.

The results show that the average of moisture content of the fish feed pellets was $17.03 \pm 0.99,16.68 \pm 1.72,17.56 \pm 1.04$ and $16.95 \pm$ $1.91 \%$ for $1.0,1.5,2.2$ and $3.0 \mathrm{~mm}$ pellets sizes, respectively, at $27 \%$ protein ratio. The highest value of $\mathrm{CV}$ of the moisture content $(0.11)$ on the $3.0 \mathrm{~mm}$ pellet sizes, while the minimum value $(0.06)$ on the 1.0 and $2.2 \mathrm{~mm}$ pellet sizes at $27 \%$ protein ratio.

The results show that the average of moisture content of the fish

\begin{tabular}{|c|c|c|c|c|c|c|c|c|c|}
\hline \multirow{3}{*}{\multicolumn{2}{|c|}{$\begin{array}{l}\text { Protein ratio } \\
(\%)\end{array}$}} & \multicolumn{4}{|c|}{ Pellet Sizes (mm) } & \multicolumn{4}{|c|}{ Pellet Sizes (mm) } \\
\hline & & 1 & 1.5 & 2.2 & 3 & 1 & 1.5 & 2.2 & 3 \\
\hline & & \multicolumn{4}{|c|}{ Durability (\%) } & \multicolumn{4}{|c|}{ Floatability (\%) } \\
\hline \multirow{3}{*}{25} & Mean & 92.62 & 87.98 & 83.33 & 75.64 & 96.45 & 93.72 & 91.55 & 79.51 \\
\hline & SD & 3.86 & 2.82 & 5.03 & 5.73 & 1.02 & 2.32 & 2.17 & 2.01 \\
\hline & CV & 0.04 & 0.03 & 0.06 & 0.08 & 0.01 & 0.02 & 0.02 & 0.03 \\
\hline \multirow{3}{*}{27} & Mean & 91.08 & 85.44 & 80.97 & 74.01 & 97.26 & 94.05 & 91.31 & 84.63 \\
\hline & SD & 3.68 & 5.00 & 3.35 & 6.90 & 0.50 & 2.51 & 2.99 & 2.65 \\
\hline & CV & 0.04 & 0.06 & 0.04 & 0.09 & 0.01 & 0.03 & 0.03 & 0.03 \\
\hline \multirow{3}{*}{30} & Mean & 87.91 & 83.03 & 78.01 & 72.84 & 97.03 & 94.88 & 93.24 & 85.01 \\
\hline & SD & 5.96 & 5.11 & 6.39 & 5.55 & 0.70 & 2.05 & 2.93 & 3.72 \\
\hline & CV & 0.07 & 0.06 & 0.08 & 0.08 & 0.01 & 0.02 & 0.03 & 0.04 \\
\hline \multirow{3}{*}{32} & Mean & 87.52 & 80.69 & 74.99 & 70.66 & 98.00 & 95.51 & 94.02 & 87.82 \\
\hline & SD & 4.44 & 4.75 & 3.18 & 4.22 & 0.00 & 2.11 & 2.07 & 2.01 \\
\hline & $\mathrm{CV}$ & 0.05 & 0.06 & 0.04 & 0.06 & 0.00 & 0.02 & 0.02 & 0.02 \\
\hline
\end{tabular}
feed pellets was $17.50 \pm 1.11,17.54 \pm 1.54,16.99 \pm 1.36$ and $17.82 \pm$ $0.98 \%$ for $1.0,1.5,2.2$ and $3.0 \mathrm{~mm}$ pellets sizes, respectively, at $30 \%$ protein ratio. The highest value of $\mathrm{CV}$ of the moisture content $(0.09)$ on the $1.5 \mathrm{~mm}$ pellet sizes, while the minimum value $(0.05)$ on the $3.0 \mathrm{~mm}$

\begin{tabular}{|c|c|c|c|c|c|c|c|c|c|}
\hline \multirow{3}{*}{\multicolumn{2}{|c|}{$\begin{array}{l}\text { Protein ratio } \\
(\%)\end{array}$}} & \multicolumn{4}{|c|}{ Pellet Sizes (mm) } & \multicolumn{4}{|c|}{ Pellet Sizes (mm) } \\
\hline & & 1 & 1.5 & 2.2 & 3 & 1 & 1.5 & 2.2 & 3 \\
\hline & & \multicolumn{4}{|c|}{ Moisture content (\%) } & \multicolumn{4}{|c|}{ Water Stability (\%) } \\
\hline \multirow{3}{*}{25} & Mean & 16.72 & 17.01 & 16.92 & 17.35 & 54.15 & 69.60 & 71.73 & 76.51 \\
\hline & SD & 2.11 & 2.03 & 1.75 & 1.32 & 4.05 & 3.93 & 3.81 & 4.97 \\
\hline & CV & 0.13 & 0.12 & 0.10 & 0.08 & 0.07 & 0.06 & 0.05 & 0.06 \\
\hline \multirow{3}{*}{27} & Mean & 17.03 & 16.68 & 17.56 & 16.95 & 57.89 & 71.36 & 75.03 & 79.62 \\
\hline & SD & 0.99 & 1.72 & 1.04 & 1.91 & 3.83 & 4.07 & 4.22 & 3.61 \\
\hline & CV & 0.06 & 0.10 & 0.06 & 0.11 & 0.07 & 0.06 & 0.06 & 0.05 \\
\hline \multirow{3}{*}{30} & Mean & 17.50 & 17.54 & 16.99 & 17.82 & 58.91 & 73.49 & 78.94 & 84.25 \\
\hline & SD & 1.11 & 1.54 & 1.36 & 0.98 & 3.72 & 4.12 & 3.96 & 3.73 \\
\hline & CV & 0.06 & 0.09 & 0.08 & 0.05 & 0.06 & 0.06 & 0.05 & 0.04 \\
\hline \multirow{3}{*}{32} & Mean & 17.20 & 16.93 & 17.77 & 17.36 & 60.65 & 76.55 & 82.14 & 91.78 \\
\hline & SD & 1.03 & 1.00 & 0.96 & 1.05 & 3.38 & 2.86 & 3.00 & 2.50 \\
\hline & CV & 0.06 & 0.06 & 0.05 & 0.06 & 0.06 & 0.04 & 0.04 & 0.03 \\
\hline
\end{tabular}
pellet sizes at $30 \%$ protein ratio.

The results show that the average of moisture content of the fish feed pellets was $17.20 \pm 1.03,16.93 \pm 1.00,17.77 \pm 0.96$ and $17.36 \pm$

SD: Standard Division

CV: Coefficient of Variation

Table 5: The mean of durability and floatability of pellets feed fish

SD: Standard Division

CV: Coefficient of Variation

Table 6: The mean of moisture content and water stability of pellets feed fish 
$1.05 \%$ for $1.0,1.5,2.2$ and $3.0 \mathrm{~mm}$ pellets sizes, respectively, at $32 \%$ protein ratio. The highest value of $\mathrm{CV}$ of the moisture content $(0.06)$ on the $1.0,1.5$ and $3.0 \mathrm{~mm}$ pellet sizes, while the minimum value $(0.05)$ on the $2.2 \mathrm{~mm}$ pellet sizes at $32 \%$ protein ratio.

The results indicated that the mean water stability of the fish feed pellets increases with increasing the pellet sizes and protein ratio. It indicated that when the pellet sizes increased from 1.0 to $3.0 \mathrm{~mm}$, the mean water stability increased from $54.15 \pm 4.05$ to $76.51 \pm 4.97 \%$ at $25 \%$ protein ratio. The highest value of $\mathrm{CV}$ of the water stability $(0.07)$ on the $1.0 \mathrm{~mm}$ pellet sizes, while the minimum value (0.05) on the 2.2 $\mathrm{mm}$ pellet sizes at $25 \%$ protein ratio.

Also, the results indicated that when the pellet sizes increased from 1.0 to $3.0 \mathrm{~mm}$, the mean water stability increased from $60.65 \pm 3.38$ to $91.78 \pm 2.50 \%$ at $32 \%$ protein ratio. These results were in agreement with those obtained by [24]. The highest value of CV of the water stability $(0.06)$ on the $1.0 \mathrm{~mm}$ pellet sizes, while the minimum value (0.03) on the $3.0 \mathrm{~mm}$ pellet sizes at $32 \%$ protein ratio.

Multiple regression analysis has resulted in a good relationship between the mean of moisture content (MC), pellet sizes (PS) and protein ratios (PR), where, the mean of moisture content has a high correlation with both PS and PR with $\mathrm{r}^{2}$ of 0.729 at $\mathrm{P}<0.001$. The mean of water stability (WS), pellet sizes (PS) and protein ratios (PR) relationship with $\mathrm{r}^{2}$ of 0.839 at $\mathrm{P}<0.001$. The best forms were as follows: $\mathrm{MC}=15.2167+0.1596 \mathrm{PS}+0.0591 \mathrm{PR} \quad \mathrm{R}^{2}=0.729 \quad$ (10) $W S=12.6707+11.4459 \mathrm{PS}+1.3318 \mathrm{PR} \quad \mathrm{R}^{2}=0.839$

Where:

MC is the moisture content of pellets fish feed, \%

WS is the water stability of pellets fish feed, \%

\section{Mechanical properties}

Repose angle and crushing load of fish feed pellets: Table 7 shows the mean values, Standard Deviation (SD) and coefficients of variation (CV) of the repose angle and crushing load of the fish feed pellets. The results indicated that the mean repose angle and crushing load of the fish feed pellets increases with increasing the pellet sizes and decreasing protein ratio. It indicated that when the pellet sizes increased from 1.0 to $3.0 \mathrm{~mm}$, the mean repose angle and crushing load increased from $28.67 \pm 0.27$ to $38.00 \pm 0.94$ degrees and $8.65 \pm 0.70$ to $33.28 \pm 1.99 \mathrm{~N}$, respectively, at $25 \%$ protein ratio. The highest value of $\mathrm{CV}$ for repose angle (0.02) was found of 1.5, 2.2 and $3.0 \mathrm{~mm}$ pellet sizes, while the highest value of $\mathrm{CV}$ for crushing load (0.08) was found for $1.0 \mathrm{~mm}$ pellet sizes. The lowest value of CV of repose angle (0.01) was found for 1.0 and $2.2 \mathrm{~mm}$ pellet sizes, while the lowest value of $\mathrm{CV}$ of crushing load (0.03) was found for $2.2 \mathrm{~mm}$ pellet sizes at $25 \%$ protein ratio.

The results indicated that when the pellet sizes increased from 1.0 to $3.0 \mathrm{~mm}$, the mean repose angle and crushing load increased from $27.00 \pm 0.47$ to $35.67 \pm 0.54$ degrees and $6.13 \pm 0.33$ to $24.98 \pm 1.15 \mathrm{~N}$, respectively, at $32 \%$ protein ratio. The highest value of $\mathrm{CV}$ for repose angle (0.02) was found for $3.0 \mathrm{~mm}$ pellet sizes, while the highest value of CV for crushing load (0.11) was found for $2.2 \mathrm{~mm}$ pellet sizes. The lowest value of CV of repose angle (0.01) was found for 1.0, 1.5 and 2.2 $\mathrm{mm}$ pellet sizes, while the lowest value of CV of crushing load (0.05) was found for $3.0 \mathrm{~mm}$ pellet sizes at $32 \%$ protein ratio.

The lowest value of repose angle and crushing load were $27.00 \pm 0.47$ degrees and $6.13 \pm 0.33 \mathrm{~N}$, respectively, at the pellet sizes $1.0 \mathrm{~mm}$ with $32 \%$ protein ratio and the highest value of repose angle and crushing load were $38.00 \pm 0.94$ degrees and $33.28 \pm 1.99 \mathrm{~N}$, respectively, at the pellet sizes $3.0 \mathrm{~mm}$ with $25 \%$ protein ratio.
Multiple regression analysis has resulted in a good relationship between the mean of Repose Angle (RA), Pellet Sizes (PS) and Protein Ratios (PR), where, the mean repose angle has a high correlation with both PS and PR with $\mathrm{r}^{2}$ of 0.988 at $\mathrm{P}<0.001$. The mean of Crushing Load (CL), Pellet Sizes (PS) and Protein Ratios (PR) relationship with $\mathrm{r}^{2}$ of 0.896 at $\mathrm{P}<0.001$. The best forms were as follows:

$$
\begin{array}{ll}
\mathrm{RP}=29.999+4.4151 \mathrm{PS}-0.217 \mathrm{PR} & \mathrm{R}^{2}=0.988 \\
C L=25.2367+11.6199 \mathrm{PS}-1.077 \mathrm{PR} & \mathrm{R}^{2}=0.896
\end{array}
$$

Where:

$\mathrm{RP}$ is the repose angle of pellets fish feed, degree

WS is the crushing load of pellets fish feed, $\mathrm{N}$

\section{Conclusion}

An experimental study was carried out successively to determine the physical and mechanical properties of extruded fish feed with different protein ratios $(25,27,30$ and $32 \%)$ and different sizes $(1.0,1.5$, 2.2 and 3.0). The obtained results can be summarized as follows:

The actual diameter of pellets fish feed value ranged from $1.51 \pm 0.17$ to $4.55 \pm 0.22 \mathrm{~mm}$ with CV of 0.04 to 0.06

The expansion rate of pellets fish feed value ranged from $33.31 \pm 6.45$ to $40.94 \pm 2.52 \%$ with CV of 0.09 to 0.19 .

The surface area of pellets fish feed value ranged from 10.57 \pm 1.69 to $71.13 \pm 9.96 \mathrm{~mm}^{2}$ with $\mathrm{CV}$ of 0.05 to 0.92 .

The volume of pellets fish feed $4.04 \pm 0.98$ to $79.09 \pm 13.04$ $\mathrm{mm}^{3}$ with $\mathrm{CV}$ of 0.08 to 0.30 .

The mean weight of the fish feed pellets increases with increasing the pellet sizes and protein ratio. It indicated that when the pellet sizes increased from 1.0 to $3.0 \mathrm{~mm}$, the mean weight of 100 pellets increased from $0.28 \pm 0.038$ to $5.51 \pm 0.237$ and $0.11 \pm 0.006$ to $3.70 \pm 0.173 \mathrm{~g}$ at 25 and $32 \%$ protein ratio, respectively.

The mean bulk density of the fish feed pellets increases with increasing the pellet sizes and protein ratio. It indicated that when the pellet sizes increased from 1.0 to $3.0 \mathrm{~mm}$, the mean bulk density increased from $630.02 \pm 156.99$ to $711.35 \pm 105.60$ and $267.11 \pm 117.65$ to $505.78 \pm 63.61 \mathrm{~kg} \mathrm{~m}^{-3}$ at 25 and $32 \%$ protein ratio, respectively.

The mean durability of fish feed pellets decreases with

\begin{tabular}{|c|c|c|c|c|c|c|c|c|c|}
\hline \multirow{3}{*}{\multicolumn{2}{|c|}{$\begin{array}{l}\text { Protein ratio } \\
(\%)\end{array}$}} & \multicolumn{4}{|c|}{ Pellet Sizes (mm) } & \multicolumn{4}{|c|}{ Pellet Sizes (mm) } \\
\hline & & 1 & 1.5 & 2.2 & 3 & 1 & 1.5 & 2.2 & 3 \\
\hline & & \multicolumn{4}{|c|}{ Repose Angle } & \multicolumn{4}{|c|}{ Crashing Load (N) } \\
\hline \multirow{3}{*}{25} & Mean & 28.67 & 31.00 & 34.67 & 38.00 & 8.65 & 11.57 & 30.00 & 33.28 \\
\hline & SD & 0.27 & 0.47 & 0.72 & 0.94 & 0.70 & 0.56 & 0.82 & 1.99 \\
\hline & CV & 0.01 & 0.02 & 0.02 & 0.02 & 0.08 & 0.05 & 0.03 & 0.06 \\
\hline \multirow{3}{*}{27} & Mean & 28.33 & 30.67 & 34.00 & 37.33 & 7.27 & 8.83 & 26.53 & 30.70 \\
\hline & SD & 0.54 & 0.72 & 0.47 & 1.19 & 0.35 & 1.24 & 1.75 & 3.79 \\
\hline & CV & 0.02 & 0.02 & 0.01 & 0.03 & 0.05 & 0.14 & 0.07 & 0.12 \\
\hline \multirow{3}{*}{30} & Mean & 28.00 & 30.67 & 33.00 & 36.67 & 6.48 & 8.90 & 19.43 & 25.27 \\
\hline & SD & 0.47 & 0.27 & 0.47 & 1.36 & 0.47 & 1.22 & 0.70 & 1.53 \\
\hline & CV & 0.02 & 0.01 & 0.01 & 0.04 & 0.07 & 0.14 & 0.04 & 0.06 \\
\hline \multirow{3}{*}{32} & Mean & 27.00 & 30.33 & 33.00 & 35.67 & 6.13 & 8.00 & 14.36 & 24.98 \\
\hline & SD & 0.47 & 0.27 & 0.47 & 0.54 & 0.33 & 0.71 & 1.52 & 1.15 \\
\hline & CV & 0.01 & 0.01 & 0.01 & 0.02 & 0.08 & 0.09 & 0.11 & 0.05 \\
\hline
\end{tabular}
increasing the pellet sizes and protein ratio. It indicated that when the

SD: Standard Division

CV: Coefficient of Variation

Table 7: The mean of Repose angle and crushing load of pellets feed fish 
Citation: Khater EG, Bahnasawy AH, Ali SA (2014) Physical and Mechanical Properties of Fish Feed Pellets. J Food Process Technol 5: 378. doi: 10.4172/2157-7110.1000378

pellet sizes increased from 1.0 to $3.0 \mathrm{~mm}$, the mean durability decreased from $92.62 \pm 3.86$ to $75.64 \pm 5.73$ and $87.52 \pm 4.44$ to $70.66 \pm 4.22 \%$ at 25 and $32 \%$ protein ratio, respectively.

The mean floatability of the fish feed pellets decreases with increasing the pellet sizes and decreasing protein ratio. It indicated that when the pellet sizes increased from 1.0 to $3.0 \mathrm{~mm}$, the mean floatability decreased from $96.45 \pm 1.02$ to $79.51 \pm 2.01$ and $98.00 \pm 0.00$ to $87.82 \pm$ $2.01 \%$ at 25 and $32 \%$ protein ratio, respectively.

The moisture content of pellets of fish feed value ranged from $16.68 \pm 1.72$ to $17.82 \pm 0.98 \%$ with $\mathrm{CV}$ of 0.05 to 0.13 .

The mean water stability of the fish feed pellets increases with increasing the pellet sizes and protein ratio. It indicated that when the pellet sizes increased from 1.0 to $3.0 \mathrm{~mm}$, the mean water stability increased from $54.15 \pm 4.05$ to $76.51 \pm 4.97$ and $60.65 \pm 3.38$ to $91.78 \pm$ $2.50 \%$ at 25 and $32 \%$ protein ratio, respectively.

The mean repose angle of the fish feed pellets increases with increasing the pellet sizes and decreasing protein ratio. It indicated that when the pellet sizes increased from 1.0 to $3.0 \mathrm{~mm}$, the mean repose angle increased from $28.67 \pm 0.27$ to $38.00 \pm 0.94$ and $27.00 \pm 0.47$ to $35.67 \pm 0.54$ degrees at 25 and $32 \%$ protein ratio, respectively.

The mean crushing load of the fish feed pellets increases with increasing the pellet sizes and decreasing protein ratio. It indicated that when the pellet sizes increased from 1.0 to $3.0 \mathrm{~mm}$, the mean crushing load increased from $8.65 \pm 0.70$ to $33.28 \pm 1.99$ and $6.13 \pm 0.33$ to 24.98 $\pm 1.15 \mathrm{~N}$, respectively, at 25 and $32 \%$ protein ratio, respectively.

\section{References}

1. Kannadhason S, Muthukumarappan K, Rosentrater KA (2011) Effect of starch sources and protein content on extruded aquaculture feed containing DDGS. Food Bioprocess Technol 4: 282-294.

2. Chang YK, Wang SS (1999) Advances in Extrusion Technology: Aquaculture Animal Feeds \& Foods. Technomic Publishing Company, Lancaster, PA.

3. Gleeson V, O'Sullivan M, Evans A (1999) Optimisation of the physical quality of aquaculture feeds by twin screw extrusion. An empirical modeling approach using response surface methodology I. Partial replacement of fish meal by grain legume protein concentrates in feeds for Atlantic salmon (Salmosalar). Replacement of Fish Meal in Aquaculture Diets: Feed Processing Project 93/120-06. Final Report to Fisheries Research \& Development Corporation (FRDC), NSW Fisheries, Sydney, Australia.

4. Barrows FT, Stone DA, Hardy RW (2007) The effects of extrusion conditions on the nutritional value of soybean meal for rainbow trout (Oncorhynchusmykiss). Aquacult 265: 244-252.

5. Aarseth KA, Perez V, Boe JK, Jeksrud WK (2006) Reliable pneumatic conveying of fish feed. Aquacult Eng 35: 14-25.

6. Thomas M, van der Poel AF (1996) Physical quality of pelleted animal feed 1 Criteria for pellet quality. Anim Feed Sci Technol 61: 89-112.

7. Hilton JW, Cho CY, Slinger SJ (1981) Effect of extrusion processing and steam pelleting diets on pellet durability, pellet water absorption, and the physiological response of rainbow trout (SalmoGaird Neri R.). Aquacult 25: 185-194.

8. Findlay R, Watling L (1994) Toward a process level model to predict the effects of salmon net-pen aquaculture on the benthos. In Modeling Benthic Impacts of Organic Enrichment from Marine Aquaculture, Canadian Technical Report of Fisheries and Aquatic Sciences 1949: xi + 125 p. B.T. Hargrove.
9. Chen Y, Beveridge M, Telfer T (1999a) Physical characteristics of commercial pelleted atlantic salmon feeds and consideration of implications for modeling of waste dispersion through sedimentation. Aquacult Int 7: 89-100.

10. Elberizon I, Kelly L (1998) Settling measurements of parameters critical to modeling benthic impacts of freshwater salmonid cage aquaculture. Aquacult. Res. 29: 669-677.

11. Sørensen M, Nguyen G, Storebakken T, Øverland M (2010) Starch source screw configuration and injection of steam into the barrel affect physical quality of extruded fish feed. Aquacult Res 41: 419-432.

12. Sørensen M, Stjepanovic N, Romarheim OH, Krekling T, Storebakken T (2009) Soybean meal improves the physical quality of extruded fish feed. Anim. Feed Sci Technol 149: 149-161.

13. Sørensen M, Morken T, Kosanovic M, Overland M (2011) Pea and wheat starch possess different processing characteristics and affect physical quality and viscosity of extruded feed for Atlantic salmon. Aquacult Nut 17: 1326-1336.

14. ASAE Standard (1984) ASAE 5352.1.moisture measurement. American Society of Agric. Eng. 2950 Niles Road, St. Joseph, MI 49085-9659.

15. Sørensen M (2007) Ingredient formulation and extrusion proceeding parameters interferes with nutritional and physical quality of aqua feeds. Feed Tech Update 2: 17-20.

16. Lim C, Cuzon G (1994) Water stability of shrimp pellet: a review. Asian Fish Sci 7: 115-127.

17. Ghazavi M, Hosseini M, Mollanouri M (2008) A comparison between angle of repose and friction angle of sand. The $12^{\text {th }}$ International Conference of International Association for computer Methods and Advances in Geomechanics (IACMAG) Goa, India.

18. Mostafa HM, Bahnasawy AH (2009) Developing an appropriate system for onion grading.ISBN-NR. VDM verlag Dr. Müller Aktiengesellschaft\& Co. KG, Pub. Germany.

19. Ainsworth P, Ibanoglu S, Plunkett A, Ibanoglu E, Stojceska V (2007) Effect of brewers spent grain addition and screw speed on the selected physical and nutritional properties of an extruded snack. J Food Eng 81: 702-709.

20. Balasubramanian S, Singh N (2007) Effect of extrusion process variables and legumes on corn extrudatesbehaviour. J Food Sci Technol 44: 330-333.

21. Chevanan N, Rosentrater KA, Muthukumarappan K (2007b) Twin-screw extrusion processing of feed blends containing distillers dried grains with solubles (DDGS). Cereal Chem 84: 428-436.

22. Garber BW, Hsieh F, Huff HE (1997) Influence of particle size on the twin-screw extrusion of corn meal. Cereal Chem 74: 656-661.

23. Hernández-Diaz JR, Quintero-Ramos A, Barnard J, Balandran-Quintana RR (2007) Functional properties of extrudates prepared with blends of wheat flour/ pinto bean meal with added wheat bran. Food Sci Technol Int 13: 301-308.

24. Umar S, Kamarudin MS, Ramezani-Fard E (2013) Physical properties of extruded aquafeed with a combination of sago and tapioca starches at different moisture contents. Anim Feed Sci Technol 183: 51-55. 